\title{
Relapses in Multiple Sclerosis: Definition, Pathophysiology, Features, Imitators, and Treatment
}

\author{
Multipl Skleroz Atakları Üzerine Güncelleme: Tanım, Patofizyoloji, Özellikler, Taklitçiler
} ve Tedavi

\author{
Serhan Sevim \\ Mersin University Faculty of Medicine, Department of Neurology, Mersin, Turkey
}

\section{Summary}

Relapse in multiple sclerosis (MS) is defined as a neurologic deficit associated with an acute inflammatory demyelinating event that lasts at least 24 hours in the absence of fever and infection. Myelinoclasis and axonal transection occur in relapses. Diagnosis, prognosis, treatment, and many other features of the disease are directly related to the relapses. MS starts as the relapsing-remitting (RRMS) form in $85 \%$ of patients. A large number of relapses in the first years, polysymptomatic relapses, and pyramidal system, brain stem, and spinal cord involvement are signs of a poor outcome. The average frequency of relapses is approximately one per year during the first years of RRMS. The frequency of relapses increases during systemic infections, psychological stress, and in the first 3 months after birth. Seventy-five percent of relapses are monosymptomatic. Pseudo-relapses and paroxysmal symptoms are distinguished from relapses by their sudden onset, sudden termination, and shorter duration. Contrast enhancement is valuable in imaging, but undetectable in most relapses. The regression in the first few weeks of relapses is explained by reduction of the edema, and by remyelination in the following months. Relapses and their features are also among the main determinants of treatment. High-dose methylprednisolone and early treatment with adrenocorticotropic hormone reduce post-relapse disability and shorten the duration of relapses. Plasmapheresis is a good option for patients who do not respond to steroid treatment. Identification of relapses by patients and physicians, distinguishing them from imitators, proper evaluation, treatment when necessary, and monitoring the results are of great importance for patients with MS. The educational levels of patients and physicians regarding these parameters should be increased. Well-designed studies that evaluate the long-term effect of relapse treatment on disability are needed.

Keywords: Multiple sclerosis, relapse, definition, features, treatment

Öz

Multipl sklerozda (MS) ateş ve enfeksiyon yokken en az 24 saat süren akut enflamatuvar demiyelinizan süreçle uyumlu nörolojik defisitler atak olarak tanımlanır. Ataklarda miyelin yıkımı ve aksonal transeksiyon oluşur. Hastalığın tanısı, seyri, tedavisi ve diğer birçok özelliği ataklarla doğrudan ilişkilidir. MS hastaların $\% 85$ 'inde atak ve düzelmelerle giden formda başlar. İlk yıllarda atak sayısının fazla olması, atakların birden çok semptomla ortaya çıkması, motor sistemi içermesi, beyin sapı ya da spinal atak formunda olması kötü prognoz göstergeleridir. Atak ve düzelmelerle giden formun başlangıç yıllarında yıllık ortalama atak sayısı 1'dir. Sistemik enfeksiyonlar, psişik stres ve postpartum 3 aylık dönemde atak sıklığı artar. Atakların \%75'i monosemptomatiktir. Yalancı ataklar ve paroksismal bulgular genellikle ani başlayıp ani sonlanmalarıyla ve kısa sürmeleriyle ataklardan ayrılır. Görüntülemede kontrast tutulumu değerlidir, ancak atakların çoğunda saptanamaz. Ataklarda ilk birkaç hafta içindeki düzelme ödem etkisinin azalmasıyla, aylar içindeki düzelme ise remiyelinizasyonla açıklanır. Ataklar ve özellikleri tedavinin de ana belirleyicilerindendir. Yüksek doz metilprednizolon ve adrenokortikotropik hormon ile erken tedavi atak sonrası özürlülüğü azaltır ve atak süresini kısaltır. Plazmaferez, steroid tedavisine yanıt vermeyen hastalar için iyi bir seçenektir. Atakların hasta ve hekim tarafından tanınması, taklitçilerinden ayırt edilmesi, uygun şekilde incelenmesi, gerekli görüldüğünde tedavi edilmesi ve sonuçlarının izlemi MS hastaları için büyük önem taşır. Bunlara yönelik olarak hasta ve hekim eğitimlerinin artırılması gerekir. Atak tedavisinin uzun dönemde özürlülük üzerine etkisini değerlendiren iyi düzenekli çalışmalara gereksinim vardır.

Anahtar Kelimeler: Multipl skleroz, atak, tanım, özellikler, tedavi

Address for Correspondence/Yazışma Adresi: Serhan Sevim MD, Mersin University Faculty of Medicine, Department of Neurology, Mersin, Turkey Phone: +90 5324168894 E-mail: serhansevim@superonline.com

Received/Gelis Tarihi: 06.12.2015 Accepted/Kabul Tarihi: 10.04 .2016

(c) Turkish Journal of Neurology, Published by Galenos Publishing House.

This article is distributed under the terms of the "Creative Commons Attribution NonCommercial 4.0 International Licence (CC BY-NC 4.0)". 


\section{Introduction}

Multiple sclerosis (MS) starts as the relapsing-remitting (RRMS) form in $85 \%$ of patients (1).

Therefore; one of the most significant features of clinical manifestations is usually the emergence of new symptoms or worsening of present symptoms within days, so called relapses. The diagnosis, prognosis, treatment, and many other features of MS are directly related to the relapses. In this article, the topics discussed will be briefly relapse pathophysiology, and mainly relapse definition, characteristics, and treatment.

Relapses are the main determinants of subtypes of MS. Approximately half of untreated patients with RRMS progress to SPMS at the end of 10 years (2). The determinants of progression to SPMS are the reduction in the frequency of relapses and progression between relapses. Although there is no consensus, there is another form of MS with a pattern of relapses within worsening neurologic functions from the onset of symptoms, namely progressive-relapsing MS (PRMS) $(3,4)$.

The primary progressive form (PPMS) accounts for approximately $10-15 \%$ of cases. The suggestions of the last two years regarding subtypes of primary and SPMS forms were transformed into a definition and the active-inactive and progressive-stable subtypes were identified for both types. In this definition, the active and inactive forms are determined according to relapses and magnetic resonance imaging (MRI), and progressive or stable forms are based on disability score (5).

Prognosis in patients with MS is also directly related to relapses. The number and type of relapses within the first 5 years is important for the prediction of disease progression. Higher number of relapses in the first years, polysymptomatic relapses, and pyramidal system, brain stem and spinal cord involvement are poor prognosis indicators. Conversely, sensory relapses, fewer relapses, and relapses with optic neuritis and recovery without sequelae are good prognostic features $(6,7)$.

Early treatment of relapses with anti-inflammatory drugs such as steroids or adrenocorticotropic hormone (ACTH) reduces post-relapse disability and shortens duration of relapses $(8,9)$.

On the other hand; the efficacy of relapse treatment in preventing and reducing long term disability is not based on scientifically solid evidence. The lack of such studies can be explained by several reasons. First, such studies should be long-term studies so that they can achieve reliable results. In addition, besides relapse treatments, immunomodulators and immunosuppressants are used in almost all patients at different stages, with various medications and applications. Furthermore, relapse treatment is performed in all patients except for patients who refuse on their own requests and formation of a subgroup without relapse treatment is considered unethical in studies. One of the other main reasons is that the pharmaceutical industry promotes studies on treatments that aim to change disease course positively rather than studies on relapse treatments. The proper application of relapse treatment may be as important as immunomodulatory and immunosuppressive therapies.
- The diagnosis, prognosis, and treatment of multiple sclerosis (MS) are directly related to relapse.

- Relapses with multiple symptoms, pyramidal symptoms, brain stem and spinal cord involvement, recovery with sequel, and large numbers of relapses in the first years are signs of a poor prognosis.

- A reduction in the number of relapses and progression between relapses can indicate transformation into the secondary progressive form (SPMS).

\section{The Pathophysiology of Relapse and Symptoms}

MS relapses are characterized by following sequential events: Blood-brain barrier (BBB) disruption due to white matter lesions, immune reactive cell migration to this region, and damage to oligodendrocytes and myelin caused by these cells. Inflammation is primarily mediated by T-lymphocytes. The probable initiator of pathogenesis is the migration of autoreactive Th17 cells, first from peripheral blood into the cervical lymph nodes, then into cerebrospinal fluid (CSF), and then finally into the choroid plexus, meninges and parenchyma (10).

This is the first wave. After disruption of the BBB, more Th17 and Th1 cells invade the parenchyma in the second wave. Inflammation becomes evident with chemokines released by myelin-reactive T-cells. Changes in the expression of adhesion molecules on the surface of $\mathrm{T}$ cells and macrophages facilitate the transport of these cells across the BBB. Interleukin 1, 12, 17, and 23 have been demonstrated to play role in triggering inflammation (11). The second stage begins with migration of CD8+ T cells and more CD4 + T cells into the central nervous system (CNS). Inflammation activates microglial cells and activation of these cells is the main cause of degeneration in the early stage. Finally, myelinoclasis, demyelination, and axonal transection occur in MS relapse. Axonal transection is associated with permanent disability. It is demonstrated that axonal transaction can begin in very early stages of a MS plaque, even in the $2^{\text {nd }}$ week after its appearance in MRI (12).

The occurrence of symptoms in relapse depends on conduction blocks and delayed axonal conduction. Conduction velocity in the axolemma is associated with higher concentrations of sodium $(\mathrm{Na})$ channels in the nodes of Ranvier. Na channel density significantly decreases in the axolemma located below areas of demyelination. Consequently, conduction blocks and significant reductions in conduction velocity occur, and classic MS symptoms emerge. According to another hypothesis, formed autoantibodies adhere to $\mathrm{Na}$ channels, which makes the axolemma non-excitable and causes conduction block (13). Demyelination areas should have a minimum diameter of $4 \mathrm{~mm}$ for the formation of conduction blocks in humans. These areas were determined to have a diameter of $2.5 \mathrm{~mm}$ in rats (14).

The release of nitric oxide by glial cells in lesions has been shown to directly slow axonal conduction. Inducible "nitric oxide 
synthase" has been shown to increase in CSF in active MS. In addition to these, cytokines, especially TNF- $\alpha$ and IFN- $\gamma$, have been shown to cause a delay in conduction. This situation may also explain the worsening in MS symptoms during infections and high body temperature. Cytokines can also cause some general symptoms such as fatigue and cognitive impairment.

All or most of these theories are probably correct, and together cause MS pathogenesis and symptomatology (15).

- Th17 cells are probably the initiators of the pathogenesis.

- Inflammation becomes evident with chemokines released by myelin-reactive T-cells.

- Myelinoclasis, demyelination, and axonal transection occur in MS relapse.

- Axonal transection is the main cause of permanent disability and starts in the $2^{\text {nd }}$ week in some relapses.

- Tumor necrosis factor-alpha (TNF- $\alpha$ ) and interferon-gamma (IFN- $\gamma$ ) lead to a slowdown in conduction, and the worsening of MS symptoms during infections and high body temperature can be explained in this way.

\section{The Definition and Features of Relapse}

The definition of relapse is mainly based on clinical findings. After the last revision, it was defined in the 2010 McDonald Criteria as "patient-reported symptoms or objectively observed signs typical of an acute inflammatory demyelinating event in the CNS, current or historical, with duration of at least 24 hours, in the absence of fever or infection" (16).

A neurologist should distinguish between pseudo-relapses and true relapses. Pseudo-relapses will be discussed under the title "Relapse imitators." Relapse should be considered even if a previous symptom arises and lasts more than 24 hours, and especially if the emerging neurologic deficit is evident. Proper treatment according to relapse features should be considered because up to $70 \%$ of MS relapses are in the form of exacerbation of previous symptoms. In addition, almost all causes of pseudorelapses, mainly infections, may also trigger true relapses. The triggering effect of menstruation alone on true relapses could not be demonstrated. However, there are findings showing worsening of symptoms in the pre-menstrual period (17).

It is of great importance that patients with MS inform physicians or health care personnel about possible relapse symptoms. In a recently published study, it was shown that relapses were underreported to health care professionals, with $28 \%$ of respondents failing to report their most recent attack, and $46 \%$ declared that they had failed to report an attack in the past, even in England where MS prevalence and socio-cultural level are very high (18). In another study in patients with MS, the reporting time of relapses to MS specialist nurses and family physicians was found as 10 days and 58 days after onset, respectively (19). There have been no studies in this field in Turkey.

In previous treatment efficacy studies conducted between 1960-2008, the average frequency of relapses in placebo control groups was approximately one per year. The annual average frequency of relapses in the treatment groups was found as 0.68 in these studies (20).

In general, we know that the frequency of relapses is higher in women and at younger ages, and decreases with time. However, it is difficult to know whether this decrease is due to treatment of almost all of the patients on any occasion or to the natural course of the disease. Both may have an effect on the decrease in relapse frequency $(21,22)$.

The three unquestionable conditions with increased relapse frequency are systemic infections, psychological stress expressed by patients, and the first three months after birth $(21,22)$. In these conditions attack triggering is thought to be primarily due to changes in cytokines and nitric oxide. Other reasons are controversial. The frequency of relapses increases in the spring and slightly reduces during winter months. In the recent years, this seasonal relationship is postulated to be associated with serum vitamin D levels (23). Data coming from relevant studies show that lower vitamin D levels are associated with more frequent relapses $(24,25)$. It has been demonstrated that previously accused physical trauma, vaccinations, and epidural anesthesia do not have relapse triggering effects. The reduction in relapse frequency was found partially related with higher serum levels of vitamin D and omega- 6 fatty acids, and sunlight exposure (22).

A typical relapse reaches its peak within a few hours and days, and recovers partially or completely after a plateau period lasting days and weeks. Particularly in some of infection-triggered relapses, fluctuations may be observed or, increases or decreases in symptoms may interweave in polysymptomatic relapses. In this case, it is difficult to distinguish whether symptoms are related to a single relapse or multiple relapses (7). Therefore, there should be at least 30 days after any previous attack or a stable period to be considered as two separate relapses (26).

In addition, multiple relapses that emerge with multiple symptoms in a short period of time may mimic transformation to progressive phase, and vice versa. So, the progressive phase may be perceived as severe relapses with short intervals by patients and physicians. Although very rare, it should be noted that relapse might occur without an obvious physical finding. Relapse with fatigue and cognitive impairment may be observed $(27,28,29)$. If there are multiple paroxysmal symptoms that last more than 24 hours, this is also described as relapse (30).

Although the phrase "there should not be a systemic infection" is included in the definition of relapse, we should not forget that about one third of MS relapses are triggered by systemic infections. The risk of relapse increases during the 2-week period before and until 5 weeks after the onset of severe infections $(-2 /+5$ week rule) $(21,31)$.

Most of relapses negatively affect activities of daily living, and increase emotional stress and depression. Quality of life is reduced in patients with frequent relapses. The psychosocial burden due to relapse has a negative effect on social life and the family life of patients (6). 
The most comprehensive study ever made about MS relapse was published a short time ago. Fifty thousand relapses of approximately 15000 patients were collected using the MSBase database and it was shown that three out of four relapses were monosymptomatic. The most common type of relapse was sensory relapse (48\%). This was followed by pyramidal (34\%), brainstem (22\%), visual (20\%), cerebellar (7\%), sphincter (3\%), and cognitive dysfunction $(1.4 \%)$ relapses, respectively (32).

According to the data of another recent study that evaluated relapse symptoms from the patients' perspective, fatigue was the most common (68\%) relapse symptom expressed by patients. It was followed by leg-foot weakness $(63 \%)$, numbness-tingling $(55 \%)$, difficulty in walking $(51 \%)$, hand-arm weakness $(49 \%)$, coordination difficulties (47\%), dizziness-balance (46\%), muscle tightness-stiffness ( $46 \%$ ), cognition (thinking-memory) problems $(42 \%)$, vision problems $(34 \%)$, bladder problems (31\%), painburning-itching (27\%), bowel problems (19\%), speech changes $(16 \%)$, chewing-swallowing problems (14\%), and sexual problems (8.5\%) (33). Visual, sensory, and brainstem relapses were found more frequently in early disease and in younger patients. Pyramidal, sphincter, and cerebellar relapses were more common in older patients and in progressive disease. Women presented more often with sensory or visual symptoms. Men were more prone to pyramidal, brainstem, and cerebellar relapses.

About $70 \%$ of new relapses present with clinical signs similar to previous relapses. However, the exact same presentation is rare. Different relapses with similar phenotypes are typical. This situation is explained by the presence of new demyelination regions on or close to former remyelination regions $(32,34)$.

The data obtained in recent years show that patients with suspected relapse should be evaluated in terms of overlooked fatigue and cognitive impairment. More than half of patients $(55.2 \%)$ stated that their school or work lives were impacted and it was shown that this duration was 12.7 days on average (33).

The average frequency of relapse in the early years of RRMS is approximately one per year. About $17 \%$ of untreated relapses recover with significant sequelae (35). Each relapse causes an average of 0.24 to 0.57 residual change in the Expanded Disability Status Scale (EDSS) score and full recovery after relapses were observed in only $55 \%$ of patients in terms of EDSS scores $(36,37)$.

There is no scale used to determine the severity of relapse. However, a recently published study evaluated oral steroid administration in relapse: Relapses were identified as "severe" (increase $>2.5$ points on EDSS), "moderate" (increase 1-2.5 points on EDSS), and "mild" (increase $\leq 0.5$ points on EDSS) (38).

Full recovery from a relapse is more difficult in polysymptomatic and spinal relapses, and in the elderly. Relapses presenting with pyramidal tract and sphincter disorders have a poor long-term prognosis when compared with relapses without involvement of these systems $(39,40,41,42)$.

The prognosis in patients with insufficient regression after the initial relapse and patients who present with brainstem, cerebellum or spinal cord syndrome was worse. The mean time to progression to SSPM was 30.2 years in half of the patients with relapses recovered fully or close to fully within the first 5 years, whereas this period was 8.3 years in poor recoverers (43).

While the majority of improvement in disability occurs within the first 2-3 months in relapse, this period may sometimes even exceed 1 year. The regression in the first few weeks of relapses is explained by reduction of plaque and surrounding edema, and by remyelination in the following months (44).

- Relapse: Neurologic deficit associated with an acute inflammatory demyelinating event that lasts at least one day, in the absence of fever and infection.

- Up to 70\% of MS relapses are in the form of exacerbation of previous symptoms.

- All causes of pseudo-relapses, except menstruation, may also trigger relapse.

- The average frequency of relapses detected in natural course studies is approximately one per year.

- The frequency of relapses is higher in women and at younger ages, and decreases with time.

- The frequency of relapses increases during systemic infections, psychological stress, and in the first 3 months after birth.

- A typical relapse reaches its peak within a few hours and days, and recovers partially or completely after a plateau period of days and weeks.

- Neurologic deficits need to occur at least 30 days after any previous episode or a stable period to be considered a new relapse.

- Seventy-five percent of relapses are monosymptomatic.

- The risk of relapses increases 2 weeks before and until 5 weeks after the onset of a severe infection.

- The most common relapse symptom expressed by patients is fatigue.

- Seventeen percent of untreated relapses recover with significant sequelae.

- Regression is more difficult in polysymptomatic, spinal, and advanced-age relapses.

- Regression in the first few weeks of relapse is explained by reduction of the edema, and by remyelination in the following months.

\section{Relapse Imitators}

Pseudo-relapse; is the emergence of previous symptoms accompanied by increased body temperature as a result of febrile diseases, menstruation, hormonal disorders, hunger, and fatigue. Symptoms occur as a result of reduction block in damaged axons due to temperature increase. There are no symptoms that were not present previously and they usually last less than a day. It is always a repetition of previous symptoms. Pseudo-relapse starts with the emergence of the cause and finishes with the disappearance. It usually disappears at rest and in cold environments. 
Paroxysmal symptoms; tend to repeat and are temporary disorders such as tonic spasms, weakness, dysarthria, ataxia, trigeminal neuralgia, and Lhermitte and Uhthoff phenomena. If these symptoms last longer than 24 hours, they are qualified as relapse. Almost all of them start abruptly and end abruptly. The vast majority of them last seconds to minutes.

Daily changes can be monitored in patients, particularly in those with high disabilities, and they can be misinterpreted as relapse. The majority of these patients have no relapse expectations, and reductions and increases in symptoms are observed in an unexpected shorter time in MS relapse.

- Pseudo-relapse is the re-emergence of previous symptoms; they emerge in situations that cause increased body temperature, end abruptly with termination of these situations, and last less than 1 day.

- Paroxysmal symptoms start abruptly; end abruptly, usually last seconds, and there is no expectation of relapse.

\section{Imaging in Relapse}

Relapse is a clinical definition. Among all the features of MS, history and physical examination are foremost in the evaluation and management of patients. A neurologist can determine a relapse based on the patient's history and examination findings, even in the absence of MRI lesions. However, the importance of imaging in relapse is increasing in light of developments in the MRI field. The radiologic equivalent of a MS relapse is an acute demyelinating lesion. However, most MS lesions are silent. Only one out of 8-9 lesions causes clinical symptoms. Contrast enhancement in the plaque is important in the assessment of disease activity and demonstrates $\mathrm{BBB}$ disruption in the plaque region. Enhancement may be diffuse or ring-shaped. A portion of medium and large-sized plaques tend to show diffuse contrast enhancement initially, but then a changeover to ring-shaped enhancement in time. "Open ring" enhancement is typical for MS and is important in distinguishing plaques from tumors and abscesses (Figure 1).

The presence of contrast-enhancing lesions consistent with symptoms in imaging is valuable in terms of relapse. However, contrast enhancement cannot be detected in many MS relapses. Contrast enhancement often begins before symptoms and before the appearance of T2 lesions in routine imaging, and lasts an average of 4 weeks. In recent studies that used high-resolution MRI techniques, some lesions were reported to be detected in fluid-attenuated inversion recovery (FLAIR) sequences before contrast enhancement. In a recent study of five untreated patients with weekly-performed three-dimensional FLAIR MRI, it was shown that $11.2 \%$ of lesions were visible on FLAIR images before the appearance of contrast-enhancement and $12.5 \%$ enhanced before being apparent on FLAIR (45).

Subclinical disease activity is seen on MRI in many patients. However, contrast enhancement in patients with clinical relapse
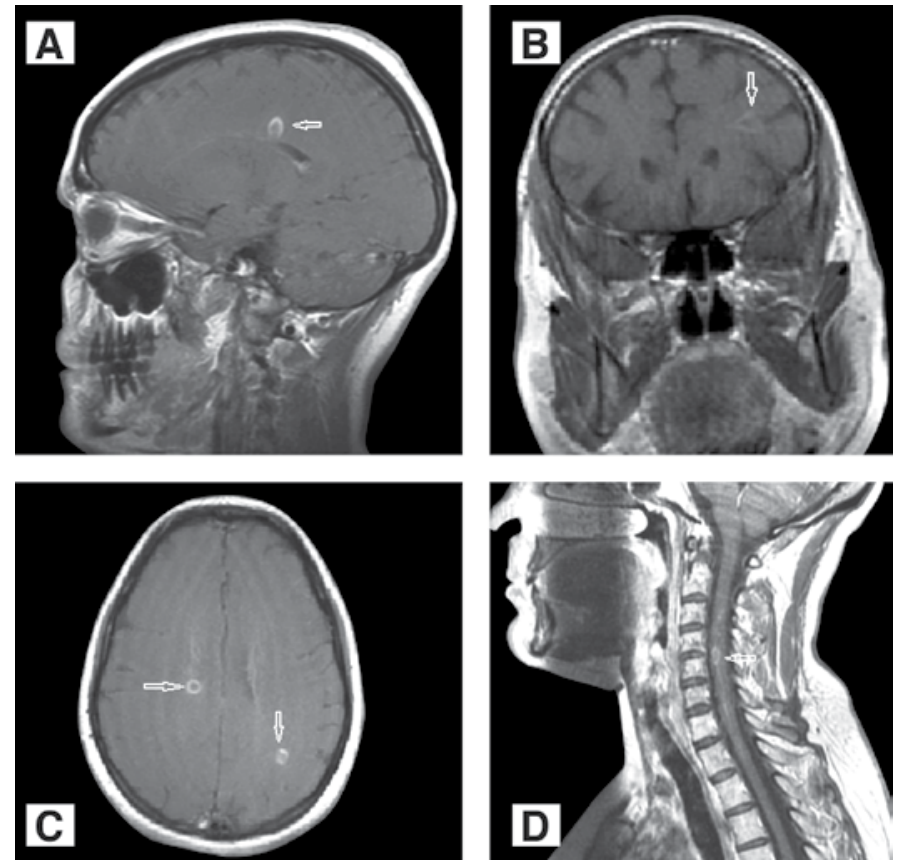

Figure 1. The "open-ring" contrast enhancement (A, B); open-ring and annular contrast enhancement $(C)$; annular contrast enhancement in spinal cord (D) (Compiled from archives of demyelinating diseases outpatient clinic, Neurology Department, Faculty of Medicine Mersin University)

is more frequent than in patients with subclinical MRI activity $(46,47,48,49)$.

In routine practice, the standard dose of gadolinium is 0.1 $\mathrm{mmol} / \mathrm{kg}$. Gadolinium is administered intravenously for at least 30 seconds. Contrast enhancement is evaluated on T1 sequences. T1 imaging should be performed in 5 minutes following contrast administration. One of the major problems in demonstrating contrast enhancement is using an insufficient amount of contrast medium in some MR centers. Contrast medium should be administered as a full dose and even a double dose if requested by a neurologist.

- Most MS plaques are silent.

- Contrast enhancement is valuable, but it is not detectable in the majority of relapses. It usually begins before symptoms and the appearance of T2 lesions, and lasts an average of 4 weeks.

- "Open ring" enhancement is typical for MS.

\section{Relapse Treatment}

The aims of relapse treatment are shortening the relapse period and preventing or reducing potential disabilities. Treatment of relapses with high doses of steroids and ACTH reduces post-relapse disability and shortens duration of relapses. Relapse treatment has secondary benefits if it is successful: It can help patients to change 
their perception that MS is an incurable disease, can strengthen the patient-physician relationship, and can improve the patient adherence to follow-up and treatment. The long-term effect of relapse treatment on disability is controversial. There are no multicenter studies with high numbers of patients creating Level I and II evidences. Although many new developments related to immunomodulatory and immunosuppressive treatments in MS have been witnessed in the last 25 years, relapse treatment has remained unchanged. Relapses are mostly treated worldwide with high dose steroids except for those presenting with pure mild to moderate sensory involvement and this treatment procedure is recommended in all guidelines.

- Treatment of relapses with intravenous methylprednisolone (IVMP) and ACTH reduces post-relapse disability and shortens the duration of relapses.

- High-dose steroids exhibit anti-inflammatory effect by both genomic and non-genomic mechanisms (dual effect).

- Maintaining oral therapy after IV administration does not provide additional benefit.

- Daily IV dosage is 500-2000 mg and the administration period is 3-10 days. It is usually administered in $100-250 \mathrm{~mL}$ of $0.9 \% \mathrm{NaCl}$ or 5-10\% dextrose solution for at least 60 minutes.

- The acute adverse effects of IVMP treatment are hyperglycemia, gastrointestinal intolerance, insomnia, euphoria, depression, metallic taste in the mouth, flushing, and infections.

- Blood pressure measurement, blood glucose, sedimentation, C-reactive protein, electrolytes analysis, and urinalysis should be performed prior to administration. Treatment should be delayed in the event of clinical signs or apparent laboratory findings of systemic infection.

- Treatment should be applied in hospital in pregnant women, children, and the elderly, and in the presence of hypertension, diabetes mellitus and peptic ulcers.

- Unresponsiveness to IVMP treatment can only be considered at least 10 days after the end of administration.

- Plasmapheresis is a good option for selected patients who are refractory to steroid treatment and who are predicted to have a permanent disability and IV immunoglobulin (Ig) treatment has no role in relapses.

\section{Adrenocorticotropic Hormone and Steroids}

After it was understood that MS was an inflammatory and autoimmune disease, anti-inflammatory drugs were introduced in MS. Steroids are still the most powerful anti-inflammatory drugs among all drug groups. Synthetic IV steroids, and rarely oral forms, are the most commonly used drugs in MS relapse. There is Level I evidence regarding accelerated clinical improvement in MS relapse provided by steroids $(50,51,52)$.

Steroids exhibit an anti-inflammatory effect by both genomic and non-genomic mechanisms (dual effect). The classic genomic mechanism recognized after the discovery of synthetic steroids which gains functionality with the activation of steroid-specific cytosolic receptors. Adrenal gland stimulation by low-dose external steroid or ACTH administration is sufficient for the activation of these receptors. The second mechanism is the nongenomic mechanism, which was discovered later and functions only by administration of very high doses of steroids. Non-genomic mechanism disrupts ion transport by direct effects on the cell membrane and induces apoptosis in divided T-cells. The efficacy of the non-genomic mechanism has been shown in experimental autoimmune encephalomyelitis, which is the experimental model of MS. Genomic and non-genomic mechanisms together compose the positive effects of steroids in MS relapse (53).

Another effect of corticosteroids is prevention of migration of inflammatory cells into the CNS. They also reduce synthesis of intrathecal immunoglobulin $\mathrm{G}$ ( $\mathrm{IgG})$, myelin basic protein, adhesion molecules, matrix metalloproteinases, and neurodegeneration products $(54,55,56)$. All these biochemical findings are indicators of positive cellular and molecular effects of steroids on relapses. Steroid administration also reduces contrast enhancement. This is believed to occur due to the repairing effect of steroids on BBB. The contrast enhancement reducing effect of steroids lasts up to 7-9 weeks (57).

The first drug used in relapse is ACTH, which has an endogenous steroid-inducing effect (58).

They are rarely used nowadays because they do not increase plasma levels of steroids as much as high-dose MP, they act later, and are more expensive. Additionally, daily administration of 500$1000 \mathrm{mg}$ of MP increases serum steroid peak levels 5-10 times more compared with ACTH administration (54). Despite these, positive effects equivalent to MP have been reported with ACTH use in relapse treatment $(59,60,61)$. This effect is attributed to the direct anti-inflammatory and immunomodulatory effects of ACTH through melanocortin receptors. ACTH is showed to be effective in opsoclonus-myoclonus and infantile spasms via the melanocortin receptors whereas synthetic steroids are found to be ineffective in these conditions $(62,63,64)$.

In practice, ACTH is administered 80 units/day intramuscularly or subcutaneously for 5-15 days. It has similar adverse effects to synthetic corticosteroids, but some patients who cannot tolerate MP treatment have been shown to tolerate ACTH treatment. It can be evaluated in patients who cannot tolerate high-dose MP therapy.

The most widely used drug in relapse treatment is MP. MP is a synthetic derivative of cortisol. It has a longer duration of action compared with cortisol, and it has a greater glucocorticoid effect but lesser mineralocorticoid effect. The half-life of circulating MP is 1.5 hours and the half-life of its metabolites is 4 hours. It reaches its peak concentration in 2 hours in plasma and 6 hours in CSF (65).

Low-dose oral maintenance therapy after IV administration is a preferred method sometimes. However, its superiority over 
IV administration alone could not be demonstrated (66). In an international optic neuritis study, administration of $1 \mathrm{~g} /$ day IV MP for 3 days followed by 21 days of oral MP has been shown to be superior to oral MP administration alone. In another randomized, controlled, prospective study, EDSS scores were shown to significantly improve in steroid-treated groups in the $3^{\text {rd }}$ and $6^{\text {th }}$ weeks (67). Two different meta-analyses also reached similar conclusions. In one of these, 377 participants from six trials were evaluated and EDSS scores in patients treated with MP or ACTH were found significantly better at the end of 1 month (relative odds ratio: 0.37 ) (68). In another meta-analysis, similar results were achieved in terms of disability scores (69).

However, in another meta-analysis of studies that comprehensively assessed treatment of optic neuritis relapses with steroids, long-term beneficial effects of high-dose steroid use on disability could not be shown (70).

Administration of high doses of oral MP during relapse has been much debated in recent years. MP was used intravenously in the majority of the studies, but was also administered orally in some. No difference was found between groups regarding drug efficiency with administration of equal doses of oral and IV MP. In a well-designed study in which oral (1250 mg/per day for 3 days) and IV (1000 mg/ per day for 3 days), MP therapies were compared in 49 patients; no differences were found between the groups in the $1^{\text {st }}, 4^{\text {th }}$, and $12^{\text {th }}$ weeks in terms of both reducing EDSS scores and MRI lesions (71). In some centers, oral steroid administration is increased in patients, particularly in those who do not require close monitoring. However, oral MP is available only in the $16 \mathrm{mg}$ form in Turkey and the patient needs to take 60-70 tablets every day. If oral administration is preferred, 25\% higher dose than IV administration may be appropriate due to loss in the gastrointestinal tract.

\section{The Adverse Effects of Steroids}

In animal studies, oligodendrocyte-mediated remyelination has been shown to decrease with steroid use (72). Results supporting increased brain atrophy with steroids are controversial. This is more likely the "pseudo-atrophy" due to anti-edema effect. Steroids are also known to exhibit adverse effects on cognition and memory. However, these effects are almost always temporary. Bone formation immediately decreases and bone resorption increases with high-dose steroid. However, this effect is also probably temporary. A negative long-term effect of high-dose steroid administration during relapses could not be demonstrated (73).

Hyperglycemia and glycosuria (5\%), gastrointestinal intolerance and dyspepsia, psychiatric effects such as insomnia, depression, and euphoria, and more rarely a metallic taste in the mouth, facial flushing, weight gain, paresthesia, and infections are among the other adverse effects of steroids. It can very rarely cause aseptic femoral head necrosis and cataracts. Acyclovir or valaciclovir can be used together if there is previous varicellazoster infection in patients taking immunosuppressant drugs (74).

It is possible to come across different information regarding steroid administration in relapses when viewed from the patient's perspective. In a study addressing this issue, one third of patients reported no adverse effects related to treatment and two-thirds reported one or more adverse events. Although one quarter of patients who reported adverse effects stated that these effects were moderate to severe, only $1 \%$ reported that they had to quit treatment because of the adverse effects. The most frequently reported adverse effect is insomnia (72\%), followed by depressed mood $(62 \%)$, metallic taste in the mouth $(59 \%)$, headache $(59 \%)$, anxiety (56\%), and swelling of the body (52\%) (20).

\section{The Intravenous Administration of Methylprednisolone in Practice}

Daily IV dose is usually $1 \mathrm{~g}$ and the administration period is $3-10$ days. It is usually administered in $100-250 \mathrm{~mL}$ of $0.9 \% \mathrm{NaCl}$ or $5-10 \%$ dextrose solution for at least 60 minutes. $\mathrm{NaCl}$ solutions and dextrose solutions are preferred in patients with diabetes and hypertension, respectively. There are also physicians who prefer $500 \mathrm{mg}$ and $2 \mathrm{~g}$ as daily doses. In a study that compared the daily administration of $2 \mathrm{~g}$ and $500 \mathrm{mg}$ IVMP, $2 \mathrm{~g}$ MP was found to be more effective in reducing the number of MRI contrast-enhanced lesions, but there were no differences regarding other measures (75).

Steroids are usually given in the morning so as to conform to the biorhythm. However, in a small study that compared IV steroid administration during the day or night in 17 patients, nighttime administration was reported to be better tolerated (76).

Blood pressure measurement, fasting blood glucose, sedimentation, C-reactive protein, electrolytes analysis, urinalysis, and chest X-ray should be performed prior to IV administration of MP. Treatment should be delayed in the event of clinical signs or laboratory findings of a systemic infection. If there are signs of asymptomatic urinary tract infection in laboratory findings, administration could be performed in conjunction with antibiotics.

If there are no contraindications, all patients should be given $\mathrm{H} 2$ receptor antagonists before administration and patients should be monitored for epigastric burning and dyspepsia. If clinical findings related to increased blood pressure emerge, patients should also be monitored at frequent intervals in this respect. The administration period should be longer in patients with cardiac diseases. Salt-free diet should be followed during administration.

Hypokalemia is the most common electrolyte disorder during administration. It should be considered in the presence of heart rhythm abnormalities and sudden weakness. The treatment should be applied in the hospital in pregnant women, children, and the elderly, and with hypertension, diabetes mellitus, and peptic ulcers.

IV administration can be applied in the $2^{\text {nd }}$ and $3^{\text {rd }}$ trimester of pregnancy, but should not be performed in the first trimester. Administration should be performed after milking the postpartum lactating mother and milk should be kept in the refrigerator. Mothers can breastfeed 4 hours after the end of administration. The baby can be fed with pre-milked milk during these 4 hours.

It is important to start high-dose steroids in the early stages (within one week) of relapse. If there is no contraindication, administration can be started on the same day in patients with severe relapse detected in the afternoon, and administration can be moved to morning hours with each new day.

The effect of high-dose steroid administration on long-term disability during relapses is controversial. There are no prospective studies in this regard and it is difficult for retrospective metaanalyses to truly reflect long-term disability. On the other hand, the 
superiority of high-dose steroid administration over placebo was shown in terms of disability and the evidence was Level I. Highdose steroid administration during relapses causing disability is recommended in all guidelines.

\section{Plasmapheresis}

Plasmapheresis and IVIg trials have begun with a better understanding of the role of humoral immunity in MS pathogenesis. Data regarding the efficacy of IVIg in relapse is not clear. Despite positive results in early studies, the results from later studies were negative. Although it is specified as a $2^{\text {nd }}$ choice in the European Federation of Neurological Societies guidelines, it has not included in America's guidelines. In a study in 76 patients treated with either IVIg or placebo in addition to steroids, there were no differences between the groups (77). Today, it has no place in relapse treatment. The situation is different for plasmapheresis and it has up to $70 \%$ efficiency in relapses refractory to steroids.

In a group of 36 patients, mostly patients with MS, with relapse who had been diagnosed as having demyelinating disease and who failed to recover after treatment with IV corticosteroids, $42 \%$ and $6 \%$ improvement in neurologic disability occurred in the group treated with plasmapheresis and in the placebo group, respectively (78). In three retrospective studies in a total of 87 patients with definitive diagnosis of MS and refractory relapses to high-dose steroids, it was reported that effective treatment was achieved with therapeutic plasma exchange in two-thirds of patients $(79,80,81)$. The situation is different for acute isolated optic neuritis refractory to high-dose steroid and no benefit from therapeutic plasma exchange could be demonstrated. However, it was found to be effective in optic neuritis accompanying neuromyelitis optica (82).

In patients with clinically isolated syndrome, acute relapse or acute worsening of symptoms, first-line treatment with therapeutic plasma exchange was found to have a $72 \%$ efficacy rate in a retrospective analysis. A median of 0.75 points reduction was achieved in EDSS scores (83). Another study showed that plasma exchange therapy was effective in relapse in SPMS; however, it had a low level of evidence (84). Unresponsiveness to steroid treatment in relapse can only be considered at least 10 days after the end of administration.

Plasmapheresis is performed via a central or peripheral venous catheter. A 1-1.5 x plasma volume is removed at each procedure every other day. A total of 5-7 exchanges are performed. It should not be performed in the event of active infection, hypotension, bradycardia, dehydration or leukopenia. The risk of serious complications is $4.6 \%$ and mortality risk is about $1.5 \%$. Serious complications may include anaphylaxis, thrombosis, sepsis, pneumothorax, hypotension, hyperthermia, hypokalemia and hypocalcemia. Good oral fluid intake should be encouraged on exchange days and the day before exchange to prevent hypotension.

Good prognostic features before plasmapheresis are short duration of illness, preserved deep tendon reflexes, and presence of surrounding edema and ring-shaped contrast enhancement on MRI (79). As a result, plasmapheresis should be performed in selected patients because of serious complications. It is a good option for relapses that are refractory to steroid treatment and that are predicted to cause permanent disability.

Although there is not enough scientific evidence available, high-dose cyclophosphamide or rituximab can be evaluated in patients who are refractory to steroid and plasma exchange therapy or in those for whom these therapies cannot be performed $(85,86)$.

\section{Conclusion}

MS relapses and their features are among the main determinants of clinical picture and treatment. Identification of relapse by patients and physicians, distinguishing them from imitators, proper evaluation, treatment when necessary, and monitoring the results are of great importance. The educational levels of patients and physicians regarding these parameters should be increased. Well-designed studies that evaluate the long-term effect of relapse treatment on disability are needed.

\section{Etbics}

\section{Peer-review: Externally peer-reviewed.}

\section{References}

1. Dutta R, Trapp BD. Relapsing and progressive forms of multiple sclerosis: insights from pathology. Curr Opin Neurol 2014;27:271-278.

2. Hauser SL, Oksenberg JR. The neurobiology of multiple sclerosis: genes, inflammation, and neurodegeneration. Neuron 2006;52:61-76.

3. Lublin FD, Reingold SC. Defining the clinical course of multiple sclerosis: results of an international survey. National Multiple Sclerosis Society (USA) Advisory Committee on Clinical Trials of New Agents in Multiple Sclerosis. Neurology 1996;46:907-911.

4. Siva A. The spectrum of multiple sclerosis and treatment decisions. Clin Neurol Neurosurg 2006;108:333-338.

5. Lublin FD. New multiple sclerosis phenotypic classification. Eur Neurol 2014;72 Suppl 1:1-5.

6. Kalincik T. Multiple Sclerosis Relapses: Epidemiology, Outcomes and Management. A Systematic Review. Neuroepidemiology 2015;44:199-214.

7. Galea I, Ward-Abel N, Heesen C. Relapse in multiple sclerosis. BMJ 2015;350:h1765.

8. Filippini G, Brusaferri F, Sibley WA, Citterio A, Ciucci G, Midgard R, Candelise L.Corticosteroids or ACTH for acute exacerbations in multiple sclerosis.Cochrane Database Syst Rev 2000;CD001331.

9. Nos C, Sastre-Garriga J, Borras C, Rio J, Tintore M, Montalban X. Clinical impact of intravenous methylprednisolone in attacks of multiple sclerosis. Mult Scler 2004;10:413-416.

10. Korn T, Bettelli E, Oukka M, Kuchroo VK. IL-17 and Th17 Cells. Annu Rev Immunol 2009;27:485-517.

11. Amedei A, Prisco D, D'Elios MM. Multiple sclerosis: the role of cytokines in pathogenesis and in therapies. Int J Mol Sci 2012;13:13438-13460.

12. Trapp BD, Peterson J, Ransohoff RM, Rudick R, Mork S, Bo L. Axonal transection in the lesions of multiple sclerosis. N Engl J Med 1998;338:278285 .

13. Smith KJ, McDonald WI. The pathophysiology of multiple sclerosis: the mechanisms underlying the production of symptoms and the natural history of the disease. Philos Trans R Soc Lond B Biol Sci 1999;354:1649-1673.

14. Davis FA. The clinico-radiological paradox in multiple sclerosis: novel implications of lesion size. Mult Scler 2014;20:515-516.

15. Lubetzki C, Stankoff B. Demyelination in multiple sclerosis. Handb Clin Neurol 2014;122:89-99.

16. Polman $\mathrm{CH}$, Reingold SC, Banwell B, Clanet M, Cohen JA, Filippi M, Fujihara K, Havrdova E, Hutchinson M, Kappos L, Lublin FD, Montalban X, O'Connor P, Sandberg-Wollheim M, Thompson AJ, Waubant E, Weinshenker B, Wolinsky JS. Diagnostic criteria for multiple sclerosis: 2010 revisions to the McDonald criteria. Ann Neurol 2011;69:292-302.

17. Zorgdrager A, De Keyser J. Menstrually related worsening of symptoms in multiple sclerosis. J Neurol Sci 1997;149:95-97. 
18. Duddy M, Lee M, Pearson O, Nikfekr E, Chaudhuri A, Percival F, Roberts $\mathrm{M}$, Whitlock C. The UK patient experience of relapse in Multiple Sclerosis treated with first disease modifying therapies. Mult Scler Relat Disord 2014;3:450-456.

19. Quinn D, Bowen A, Leary A. The value of the multiple sclerosis specialist nurse with respect to prevention of unnecessary emergency admission. Mult Scler 2014;20:1669-1670.

20. Inusah S, Sormani MP, Cofield SS, Aban IB, Musani SK, Srinivasasainagendra $\mathrm{V}$, Cutter GR. Assessing changes in relapse rates in multiple sclerosis. Mult Scler 2010;16:1414-1421.

21. Buljevac D, Flach HZ, Hop WC, Hijdra D, Laman JD, Savelkoul HF, van Der Meche FG, van Doorn PA, Hintzen RQ. Prospective study on the relationship between infections and multiple sclerosis exacerbations. Brain 2002;125:952-960.

22. D'Hooghe M B, Nagels G, Bissay V, De Keyser J. Modifiable factors influencing relapses and disability in multiple sclerosis. Mult Scler 2010;16:773-785.

23. Jin Y, de Pedro-Cuesta J, Soderstrom M, Stawiarz L, Link H. Seasonal patterns in optic neuritis and multiple sclerosis: a meta-analysis. J Neurol Sci 2000;181:56-64.

24. Runia TF, Hop WC, de Rijke YB, Buljevac D, Hintzen RQ. Lower serum vitamin $\mathrm{D}$ levels are associated with a higher relapse risk in multiple sclerosis. Neurology 2012;79:261-266.

25. Martinelli V, Dalla Costa G, Colombo B, Dalla Libera D, Rubinacci A, Filippi M, Furlan R, Comi G. Vitamin D levels and risk of multiple sclerosis in patients with clinically isolated syndromes. Mult Scler 2014;20:147155.

26. McDonald WI, Compston A, Edan G, Goodkin D, Hartung HP, Lublin FD, McFarland HF, Paty DW, Polman CH, Reingold SC, Sandberg-Wollheim M, Sibley W, Thompson A, van den Noort S, Weinshenker BY, Wolinsky JS. Recommended diagnostic criteria for multiple sclerosis: guidelines from the International Panel on the diagnosis of multiple sclerosis. Ann Neurol 2001;50:121-127.

27. Flachenecker P, Meissner H. Fatigue in multiple sclerosis presenting as acute relapse: subjective and objective assessment. Mult Scler 2008;14:274-277.

28. Larner AJ, Young CA. Acute amnesia in MS revisited. Int MS J 2009;16:102104 .

29. Coebergh JA, Roosendaal SD, Polman CH, Geurts JJ, van Woerkom TC. Acute severe memory impairment as a presenting symptom of multiple sclerosis: a clinical case study with $3 \mathrm{D}$ double inversion recovery MR imaging. Mult Scler 2010;16:1521-1524.

30. Taylor RS. Multiple sclerosis potpourri. Paroxysmal symptoms, seizures, fatigue, pregnancy, and more. Phys Med Rehabil Clin N Am 1998;9:551559.

31. Sibley WA, Bamford CR, Clark K. Clinical viral infections and multiple sclerosis. Lancet 1985;1:1313-1315.

32. Kalincik T, Buzzard K, Jokubaitis V, Trojano M, Duquette P, Izquierdo G, Girard M, Lugaresi A, Grammond P, Grand'Maison F, Oreja-Guevara C, Boz C, Hupperts R, Petersen T, Giuliani G, Iuliano G, Lechner-Scott J, Barnett M, Bergamaschi R, Van Pesch V, Amato MP, van Munster E, Fernandez-Bolanos R, Verheul F, Fiol M, Cristiano E, Slee M, Rio ME, Spitaleri D, Alroughani R, Gray O, Saladino ML, Flechter S, Herbert J, Cabrera-Gomez JA, Vella N, Paine M, Shaw C, Moore F, Vucic S, Savino A, Singhal B, Petkovska-Boskova T, Parratt J, Sirbu CA, Rozsa C, Liew D, Butzkueven H, Group MSS. Risk of relapse phenotype recurrence in multiple sclerosis. Mult Scler 2014;20:1511-1522.

33. Nickerson M, Cofield SS, Tyry T, Salter AR, Cutter GR, Marrie RA. Impact of multiple sclerosis relapse: The NARCOMS participant perspective. Mult Scler Relat Disord 2015;4:234-240.

34. Bramow S, Frischer JM, Lassmann H, Koch-Henriksen N, Lucchinetti CF, Sorensen PS, Laursen H. Demyelination versus remyelination in progressive multiple sclerosis. Brain 2010;133:2983-2998.

35. Vukusic S, Confavreux C. Natural history of multiple sclerosis: risk factors and prognostic indicators. Curr Opin Neurol 2007;20:269-274.

36. Lublin FD, Baier M, Cutter G. Effect of relapses on development of residual deficit in multiple sclerosis. Neurology 2003;61:1528-1532.

37. Hirst C, Ingram G, Pearson O, Pickersgill T, Scolding N, Robertson $\mathrm{N}$. Contribution of relapses to disability in multiple sclerosis. J Neurol 2008;255:280-287.
38. Ramo-Tello C, Grau-Lopez L, Tintore M, Rovira A, Ramio i Torrenta L, Brieva L, Cano A, Carmona O, Saiz A, Torres F, Giner P, Nos C, Massuet A, Montalban X, Martinez-Caceres E, Costa J. A randomized clinical trial of oral versus intravenous methylprednisolone for relapse of MS. Mult Scler 2014;20:717-725.

39. Kantarci O, Siva A, Eraksoy M, Karabudak R, Sutlas N, Agaoglu J, Turan F, Ozmenoglu M, Togrul E, Demirkiran M. Survival and predictors of disability in Turkish MS patients. Turkish Multiple Sclerosis Study Group (TUMSSG). Neurology 1998;51:765-772.

40. Bergamaschi R, Berzuini C, Romani A, Cosi V. Predicting secondary progression in relapsing-remitting multiple sclerosis: a Bayesian analysis. J Neurol Sci 2001;189:13-21.

41. Langer-Gould A, Popat RA, Huang SM, Cobb K, Fontoura P, Gould MK, Nelson LM. Clinical and demographic predictors of long-term disability in patients with relapsing-remitting multiple sclerosis: a systematic review. Arch Neurol 2006;63:1686-1691.

42. Leone MA, Bonissoni S, Collimedaglia L, Tesser F, Calzoni S, Stecco A, Naldi $\mathrm{P}$, Monaco F. Factors predicting incomplete recovery from relapses in multiple sclerosis: a prospective study. Mult Scler 2008;14:485-493.

43. Novotna M, Paz Soldan MM, Abou Zeid N, Kale N, Tutuncu M, Crusan DJ, Atkinson EJ, Siva A, Keegan BM, Pirko I, Pittock SJ, Lucchinetti CF, Noseworthy JH, Weinshenker BG, Rodriguez M, Kantarci OH. Poor early relapse recovery affects onset of progressive disease course in multiple sclerosis. Neurology 2015;85:722-729.

44. Noseworthy JH, Lucchinetti C, Rodriguez M, Weinshenker BG. Multiple sclerosis. N Engl J Med 2000;343:938-952.

45. Guttmann CR, Rousset M, Roch JA, Hannoun S, Durand-Dubief F, Belaroussi B, Cavallari M, Rabilloud M, Sappey-Marinier D, Vukusic S, Cotton F. Multiple sclerosis lesion formation and early evolution revisited: A weekly high-resolution magnetic resonance imaging study. Mult Scler 2016;22:761-769.

46. Gasperini C, Pozzilli C, Bastianello S, Koudriavtseva T, Colleluori A, Millefiorini E, Thompson AJ, Horsfield MA, Galgani S, Bozzao L, Fieschi C. The influence of clinical relapses and steroid therapy on the development of Gd-enhancing lesions: a longitudinal MRI study in relapsing-remitting multiple sclerosis patients. Acta Neurol Scand 1997;95:201-207.

47. Ferraro D, Simone AM, Bedin R, Galli V, Vitetta F, Federzoni L, D'Amico R, Merelli E, Nichelli PF, Sola P. Cerebrospinal fluid oligoclonal IgM bands predict early conversion to clinically definite multiple sclerosis in patients with clinically isolated syndrome. J Neuroimmunol 2013;257:76-81.

48. Tintore M, Rovira A, Rio J, Tur C, Pelayo R, Nos C, Tellez N, Perkal H, Comabella M, Sastre-Garriga J, Montalban X. Do oligoclonal bands add information to MRI in first attacks of multiple sclerosis? Neurology 2008;70:1079-1083

49. Kuhle J, Disanto G, Dobson R, Adiutori R, Bianchi L, Topping J, Bestwick JP, Meier UC, Marta M, Dalla Costa G, Runia T, Evdoshenko E, Lazareva N, Thouvenot E, Iaffaldano P, Direnzo V, Khademi M, Piehl F, Comabella M, Sombekke M, Killestein J, Hegen H, Rauch S, D'Alfonso S, AlvarezCermeno JC, Kleinova P, Horakova D, Roesler R, Lauda F, Llufriu S, Avsar T, Uygunoglu U, Altintas A, Saip S, Menge T, Rajda C, Bergamaschi R, Moll N, Khalil M, Marignier R, Dujmovic I, Larsson H, Malmestrom C, Scarpini E, Fenoglio C, Wergeland S, Laroni A, Annibali V, Romano S, Martinez AD, Carra A, Salvetti M, Uccelli A, Torkildsen O, Myhr KM, Galimberti D, Rejdak K, Lycke J, Frederiksen JL, Drulovic J, Confavreux C, Brassat D, Enzinger C, Fuchs S, Bosca I, Pelletier J, Picard C, Colombo E, Franciotta D, Derfuss T, Lindberg R, Yaldizli O, Vecsei L, Kieseier BC, Hartung HP, Villoslada P, Siva A, Saiz A, Tumani H, Havrdova E, Villar LM, Leone M, Barizzone N, Deisenhammer F, Teunissen C, Montalban X, Tintore M, Olsson T, Trojano M, Lehmann S, Castelnovo G, Lapin S, Hintzen R, Kappos L, Furlan R, Martinelli V, Comi G, Ramagopalan SV, Giovannoni G. Conversion from clinically isolated syndrome to multiple sclerosis: A large multicentre study. Mult Scler 2015;21:1013-1024.

50. Durelli L, Cocito D, Riccio A, Barile C, Bergamasco B, Baggio GF, Perla F, Delsedime M, Gusmaroli G, Bergamini L. High-dose intravenous methylprednisolone in the treatment of multiple sclerosis: clinicalimmunologic correlations. Neurology 1986;36:238-243.

51. Milligan NM, Newcombe R, Compston DA. A double-blind controlled trial of high dose methylprednisolone in patients with multiple sclerosis: 1 . Clinical effects. J Neurol Neurosurg Psychiatry 1987;50:511-516. 
52. Beck RW, Cleary PA, Anderson MM Jr, Keltner JL, Shults WT, Kaufman DI, Buckley EG, Corbett JJ, Kupersmith MJ, Miller NR. A randomized, controlled trial of corticosteroids in the treatment of acute optic neuritis. The Optic Neuritis Study Group. N Engl J Med 1992;326:581-588.

53. Gold R, Buttgereit F, Toyka KV. Mechanism of action of glucocorticosteroid hormones: possible implications for therapy of neuroimmunological disorders. J Neuroimmunol 2001;117:1-8.

54. Warren KG, Catz I, Jeffrey VM, Carroll DJ. Effect of methylprednisolone on CSF IgG parameters, myelin basic protein and anti-myelin basic protein in multiple sclerosis exacerbations. Can J Neurol Sci 1986;13:25-30.

55. Sloka JS, Stefanelli M. The mechanism of action of methylprednisolone in the treatment of multiple sclerosis. Mult Scler 2005;11:425-432.

56. Gelati M, Corsini E, De Rossi M, Masini L, Bernardi G, Massa G, Boiardi A, Salmaggi A. Methylprednisolone acts on peripheral blood mononuclear cells and endothelium in inhibiting migration phenomena in patients with multiple sclerosis. Arch Neurol 2002;59:774-780.

57. Barkhof F, Tas MW, Frequin ST, Scheltens P, Hommes OR, Nauta JJ, Valk J. Limited duration of the effect of methylprednisolone on changes on MRI in multiple sclerosis. Neuroradiology 1994;36:382-387.

58. Jonsson B, von RG, Sahlgren E. [Treatment of sclerosis disseminata with ACTH]. Nord Med 1950;43:380-381.

59. Barnes MP, Bateman DE, Cleland PG, Dick DJ, Walls TJ, Newman PK, Saunders M, Tilley PJ. Intravenous methylprednisolone for multiple sclerosis in relapse. J Neurol Neurosurg Psychiatry 1985;48:157-159.

60. Milanese C, La Mantia L, Salmaggi A, Campi A, Eoli M, Scaioli V, Nespolo A, Corridori F. Double-blind randomized trial of ACTH versus dexamethasone versus methylprednisolone in multiple sclerosis bouts. Clinical, cerebrospinal fluid and neurophysiological results. Eur Neurol 1989;29:10-14.

61. Thompson AJ, Kennard C, Swash M, Summers B, Yuill GM, Shepherd DI, Roche S, Perkin GD, Loizou LA, Ferner R. Relative efficacy of intravenous methylprednisolone and ACTH in the treatment of acute relapse in MS. Neurology 1989;39:969-971.

62. Thompson AJ, Kennard C, Swash M, Summers B, Yuill GM, Shepherd DI, Roche S, Perkin GD, Loizou LA, Ferner R, et al. Relative efficacy of intravenous methylprednisolone and ACTH in the treatment of acute relapse in MS. Neurology 1989;39:969-971.

63. Arnason BG, Berkovich R, Catania A, Lisak RP, Zaidi M. Mechanisms of action of adrenocorticotropic hormone and other melanocortins relevant to the clinical management of patients with multiple sclerosis. Mult Scler 2012;19:130-136

64. Berkovich R, Agius MA. Mechanisms of action of ACTH in the management of relapsing forms of multiple sclerosis. Ther Adv Neurol Disord 2014;7:83-96.

65. Defer GL, Barre J, Ledudal P, Tillement JP, Degos JD. Methylprednisolone infusion during acute exacerbation of MS: plasma and CSF concentrations. Eur Neurol 1995;35:143-148.

66. Perumal JS, Caon C, Hreha S, Zabad R, Tselis A, Lisak R, Khan O. Oral prednisone taper following intravenous steroids fails to improve disability or recovery from relapses in multiple sclerosis. Eur J Neurol 2008;15:677-680.

67. Sellebjerg F, Frederiksen JL, Nielsen PM, Olesen J. Double-blind, randomized, placebo-controlled study of oral, high-dose methylprednisolone in attacks of MS. Neurology 1998;51:529-534.

68. FilippiniG, Brusaferri F, Sibley WA, Citterio A, Ciucci G, Midgard R, Candelise L. Corticosteroids or ACTH for acute exacerbations in multiple sclerosis. Cochrane Database Syst Rev 2000:CD001331.

69. Miller DM, Weinstock-Guttman B, Bethoux F, Lee JC, Beck G, Block V, Durelli L, LaMantia L, Barnes D, Sellebjerg F, Rudick RA. A meta-analysis of methylprednisolone in recovery from multiple sclerosis exacerbations. Mult Scler 2000;6:267-273.

70. Gal RL, Vedula SS, Beck R. Corticosteroids for treating optic neuritis. Cochrane Database Syst Rev 2012;CD001430.
71. Ramo-Tello C, Grau-Lopez L, Tintore M, Rovira A, Ramio i Torrenta L, Brieva L, Cano A, Carmona O, Saiz A, Torres F, Giner P, Nos C, Massuet A, Montalban X, Martinez-Caceres E, Costa J. A randomized clinical trial of oral versus intravenous methylprednisolone for relapse of MS. Mult Scler 2014; $20: 717-725$.

72. Chari DM, Zhao C, Kotter MR, Blakemore WF, Franklin RJ. Corticosteroids delay remyelination of experimental demyelination in the rodent central nervous system. J Neurosci Res 2006;83:594-605.

73. Zorzon M, Zivadinov R, Locatelli L, Giuntini D, Toncic M, Bosco A, Nasuelli D, Bratina A, Tommasi MA, Rudick RA, Cazzato G. Long-term effects of intravenous high dose methylprednisolone pulses on bone mineral density in patients with multiple sclerosis. Eur J Neurol 2005;12:550-556.

74. Arvin AM, Wolinsky JS, Kappos L, Morris MI, Reder AT, Tornatore C, Gershon A, Gershon M, Levin MJ, Bezuidenhoudt M, Putzki N. Varicellazoster virus infections in patients treated with fingolimod: risk assessment and consensus recommendations for management. JAMA Neurol 2015;72:3139.

75. Oliveri RL, Valentino P, Russo C, Sibilia G, Aguglia U, Bono F, Fera F, Gambardella A, Zappia M, Pardatscher K, Quattrone A. Randomized trial comparing two different high doses of methylprednisolone in MS: a clinical and MRI study. Neurology 1998;50:1833-1836.

76. Glass-Marmor L, Paperna T, Ben-Yosef Y, Miller A. Chronotherapy using corticosteroids for multiple sclerosis relapses. J Neurol Neurosurg Psychiatry 2007;78:886-888.

77. Sorensen PS, Haas J, Sellebjerg F, Olsson T, Ravnborg M, Group TS. IV immunoglobulins as add-on treatment to methylprednisolone for acute relapses in MS. Neurology 2004;63:2028-2033.

78. Weinshenker BG, O'Brien PC, Petterson TM, Noseworthy JH, Lucchinetti CF, Dodick DW, Pineda AA, Stevens LN, Rodriguez M. A randomized trial of plasma exchange in acute central nervous system inflammatory demyelinating disease. Ann Neurol 1999;46:878-886.

79. Magana SM, Keegan BM, Weinshenker BG, Erickson BJ, Pittock SJ, Lennon VA, Rodriguez M, Thomsen K, Weigand S, Mandrekar J, Linbo L, Lucchinetti CF. Beneficial plasma exchange response in central nervous system inflammatory demyelination. Arch Neurol 2011;68:870-878.

80. Llufriu S, Castillo J, Blanco Y, Ramio-Torrenta L, Rio J, Valles M, Lozano M, Castella MD, Calabia J, Horga A, Graus F, Montalban X, Saiz A. Plasma exchange for acute attacks of CNS demyelination: Predictors of improvement at 6 months. Neurology 2009;73:949-953.

81. Trebst C, Reising A, Kielstein JT, Hafer C, Stangel M. Plasma exchange therapy in steroid-unresponsive relapses in patients with multiple sclerosis. Blood Purif 2009;28:108-115.

82. Bennett JL, Nickerson M, Costello F, Sergott RC, Calkwood JC, Galetta SL, Balcer LJ, Markowitz CE, Vartanian T, Morrow M, Moster ML, Taylor AW, Pace TW, Frohman T, Frohman EM. Re-evaluating the treatment of acute optic neuritis. J Neurol Neurosurg Psychiatry 2015;86:799-808.

83. Ehler J, Koball S, Sauer M, Mitzner S, Hickstein H, Benecke R, Zettl UK. Response to Therapeutic Plasma Exchange as a Rescue Treatment in Clinically Isolated Syndromes and Acute Worsening of Multiple Sclerosis: A Retrospective Analysis of 90 Patients. PLoS One 2015;10:e0134583.

84. Linker RA, Chan A, Sommer M, Koziolek M, Muller GA, Paulus W, Gold R. Plasma exchange therapy for steroid-refractory superimposed relapses in secondary progressive multiple sclerosis. J Neurol 2007;254:1288-1289.

85. Harrison DM, Gladstone DE, Hammond E, Cheng J, Jones RJ, Brodsky RA, Kerr D, McArthur JC, Kaplin A. Treatment of relapsing-remitting multiple sclerosis with high-dose cyclophosphamide induction followed by glatiramer acetate maintenance. Mult Scler 2012;18:202-209.

86. Sempere AP, Feliu-Rey E, Sanchez-Perez R, Nieto-Navarro J. Neurological picture. Rituximab for tumefactive demyelination refractory to corticosteroids and plasma exchange. J Neurol Neurosurg Psychiatry 2013;84:1338-1339. 